\title{
Ticks and associated pathogens in camels (Camelus dromedarius) from Riyadh Province, Saudi Arabia
}

Abdullah D. Alanazi ${ }^{*}$, Viet Linh Nguyen², Mohamed S. Alyousif ${ }^{3}$, Ranju R. S. Manoj ${ }^{2}$, Abdulaziz S. Alouffi ${ }^{4}$ Ridolfi Donato ${ }^{5}$, Alireza Sazmand ${ }^{6}$, Jairo A. Mendoza-Roldan², Filipe Dantas-Torres ${ }^{2,7}$ and Domenico Otranto $2,6^{*}$ (1)

\begin{abstract}
Background: Camel production in Saudi Arabia is severely affected by various diseases and by inadequate veterinary services. Ticks and tick-borne pathogens (TBPs) affect the health and wellbeing of camels consequently diminishing their productivity and performances. In addition, camels may act as hosts for TBPs (e.g. Anaplasma phagocytophilum) causing diseases in humans. The current study aimed to determine the prevalence of ixodid ticks and molecularly investigate the associated pathogens in camels from Saudi Arabia.
\end{abstract}

Methods: Blood and tick samples were collected from camels $(n=170)$ in Riyad Province of Saudi Arabia. Ticks were morphologically identified, and blood of camels were molecularly screened for apicomplexan (i.e. Babesia spp., Theileria spp., Hepatozoon spp.) and rickettsial parasites (i.e. Ehrlichia spp. and Anaplasma spp.).

Results: Of the 170 camels examined, 116 (68.2\%; 95\% Cl: 60.9-75.1\%) were infested by ticks with a mean intensity of 2.53 (95\% Cl: 2.4-2.6). In total of 296 ticks collected, Hyalomma dromedarii was the most prevalent (76.4\%), followed by Hyalomma impeltatum (23.3\%) and Hyalomma excavatum (0.3\%). Of the tested animals, 13 (7.6\%; 95\% Cl: 4.3-12.8\%) scored positive to at least one TBP, with Anaplasma platys (5.3\%; 95\% Cl: 2.7-9.9\%) being the most prevalent species, followed by Anaplasma phagocytophilum, Anaplasma sp., Ehrlichia canis and Hepatozoon canis (0.6\% each; $95 \%$ Cl: 0.04-3.4\%). None of the camels were found to be co-infected with more than one pathogen. All samples tested negative for Babesia spp. and Theileria spp.

Conclusions: The present study reveals the occurrence of different tick species and TBPs in camels from Saudi Arabia. Importantly, these camels may carry A. phagocytophilum and A. platys, representing a potential risk to humans.

Keywords: Ticks, Tick-borne pathogens, Camels, Saudi Arabia, Anaplasma platys, Anaplasma phagocytophilum, Ehrlichia canis, Hepatozoon canis

\footnotetext{
*Correspondence: aalanazi@su.edu.sa; domenico.otranto@uniba.it

${ }^{1}$ Department of Biological Sciences, Faculty of Science and Humanities,

Shaqra University, Ad-Dawadimi, Saudi Arabia

${ }^{2}$ Dipartimento di Medicina Veterinaria, Università degli Studi di Bari, Bari,

Italy

Full list of author information is available at the end of the article
}

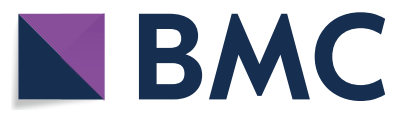

(C) The Author(s) 2020. This article is licensed under a Creative Commons Attribution 4.0 International License, which permits use, sharing, adaptation, distribution and reproduction in any medium or format, as long as you give appropriate credit to the original author(s) and the source, provide a link to the Creative Commons licence, and indicate if changes were made. The images or other third party material in this article are included in the article's Creative Commons licence, unless indicated otherwise in a credit line to the material. If material is not included in the article's Creative Commons licence and your intended use is not permitted by statutory regulation or exceeds the permitted use, you will need to obtain permission directly from the copyright holder. To view a copy of this licence, visit http://creativeco mmons.org/licenses/by/4.0/. The Creative Commons Public Domain Dedication waiver (http://creativecommons.org/publicdomain/ zero/1.0/) applies to the data made available in this article, unless otherwise stated in a credit line to the data. 


\section{Background}

Ticks and transmitted tick-borne pathogens (TBPs) may cause a serious threat to humans, livestock, pets, and wildlife throughout the world $[1,2]$. In addition to acting as the vectors of pathogens, ticks also affect the wellbeing of livestock directly through irritating bites, blood loss, damage to the skin and anorexia, leading to reduced growth [3]. Saudi Arabia is listed among the countries with a recent high growth in the camel population [4], having a population of approximately 500,000 in 2017 with the highest percentage in Riyadh Province [5]. The genus Camelus includes two species, Camelus dromedarius (Arabian camel or dromedary) distributed in North Africa and the Middle East, and Camelus bactrianus (Bactrian camel) in cold steppes and the deserts of Central Asia [6]. The dromedary camel plays an important role in the economy, especially in the culture of Arabian countries. Apart from being adapted to the harsh environment, these pseudo-ruminants, popularly known as "ship of the deserts" are multipurpose animals used for milk and meat production, hair/felt, racing, transportation and tourism [4, 6]. Camel production is severely affected by various diseases, especially in the absence of adequate veterinary services [7]. Many endo- and ectoparasites affect their health, productivity and performance including ticks [7], with more than 20 ixodid species found to infest camels $[8,9]$. Among them, ticks of the genus Hyalomma are the most prevalent species $[10,11]$, which could act as vectors for Theileria spp. (i.e. Theileria annulata and Theileria ovis), Babesia spp. (i.e. Babesia bigemina, Babesia caballi, Babesia ovis) [12-15] and Anaplasma spp. [12]. Nonetheless, the role of Hyalomma spp. ticks as competent vectors of many of these pathogens is still uncertain.

Although genus Anaplasma includes six recognized species, $A$. phagocytophilum is the major zoonotic pathogen [16]. Apart from humans, A. phagocytophilum has been detected in dogs, horses, cats, sheep, goats, cattle and camels $[17,18]$. In addition, three new possible Anaplasma species, Anaplasma odocoilei [19], Anaplasma capra [20] and "Candidatus Anaplasma camelii" [21] have recently been reported from deer, goats and camels, respectively. Being largely imported from neighboring countries, livestock may serve as a source of pathogens to camels in Saudi Arabia [22]. Conventional microscopic examination revealed the presence of TBPs such as Anaplasma spp., Babesia spp. and Theileria spp. in camels of Saudi Arabia [23-25]. However, knowledge of TBPs in camels of this country is very limited with few molecular epidemiological studies conducted on a limited number of animals $[15,26]$. Therefore, the present study aimed to determine the prevalence of ixodid ticks and molecularly investigate their associated pathogens in camels from Saudi Arabia.

\section{Methods \\ Sampling procedures}

From March to September 2018, a total of 170 camels were screened to assess the intensity of tick infestation and the prevalence of TBPs. Camels came from Riyadh Province $\left(24^{\circ} 0^{\prime} \mathrm{N}, 45^{\circ} 30^{\prime} \mathrm{E}\right)$, the central part of Saudi Arabia. Each camel was apparently healthy at the time of sampling and was screened for tick infestation. Ticks found within 15 min were collected (2-5 ticks/infested animal), placed in labeled tubes individualized per camel, containing $70 \%$ ethanol. Ticks were identified to the species level by using morphological keys and descriptions [27-34]. Categorical data on age and sex was also collected from each camel. Approximately $2 \mathrm{ml}$ of blood was collected from the cephalic vein of camels and preserved in $\mathrm{K}_{3}$ EDTA coated vacutainer tubes (BD Vacutainer ${ }^{\circledR}$ Tube, BD Diagnostic Systems, Melbourne, Australia) until DNA extraction.

\section{DNA isolation from camel blood, molecular analysis by PCR and sequencing}

Genomic DNA was isolated from whole blood samples using the Wizard ${ }^{\circledR}$ Genomic DNA Purification Kit (Promega, Madison, WI, USA), following the manufacturer's instructions and was stored at $-80^{\circ} \mathrm{C}$. All DNA samples were tested for the presence of apicomplexan (i.e. Babesia spp., Theileria spp. and Hepatozoon spp.) and rickettsial parasites (i.e. Ehrlichia spp. and Anaplasma spp.) by conventional PCR (CPCR) using primers targeting partial 18S rRNA and 16S rRNA genes, as described previously [3538] (Table 1). Initially, a single PCR reaction was used for the simultaneous detection of apicomplexan and rickettsial pathogens. Individual species-specific PCRs were then performed (Table 1) in the positive samples to assess the co-infections with more than one parasite species. For all reactions, DNA of pathogen-positive blood samples served as a positive control. Amplified PCR products were examined on $2 \%$ agarose gels stained with GelRed (VWR International PBI, Milan, Italy) and visualized on a GelLogic 100 gel documentation system (Kodak, New York, USA). The PCR products were purified and sequenced in both directions using the same forward and reverse primers, employing the Big Dye Terminator v.3.1 chemistry in a 3130 Genetic analyzer (Applied Biosystems, California, USA) in an automated sequencer (ABI-PRISM 377). Gene sequences were edited, aligned and analyzed using the Geneious platform version 9.0 (Biomatters Ltd., Auckland, New Zealand) and compared with the available sequences in GenBank using the Basic 
Local Alignment Search Tool (BLAST; http://blast.ncbi. nlm.nih.gov/Blast.cgi).

\section{Phylogenetic analysis}

Phylogenetic relationships were inferred using the Maximum Likelihood (ML) method based on the Kimura 2-parameter model [39], Hasegawa-Kishino-Yano model [40] with the Gamma distribution (+G) were used to model evolutionary rate differences among sites selected by the best-fit model [41]. Evolutionary analysis was conducted on 8000 bootstrap replications using the MEGA $\mathrm{X}$ software [42]. Homologous sequences from Adelina bambarooniae and Wolbachia pipientis were used as the outgroups (GenBank: AF494058 and AF179630, respectively).

\section{Statistical analysis}

Prevalence (i.e. proportion of hosts infested by ticks), tick infestation burden (i.e. arithmetic mean count of ticks on each infested host) and pathogen infection rates were assessed using Quantitative Parasitology software (version 3.0) [43].

\section{Results}

Of the 170 camels examined, 116 (68.2\%; 95\% CI: 60.9$75.1 \%$ ) were infested by 296 ticks (mean intensity of 2.53; 95\% CI: 2.4-2.6), with 206 (69.6\%) being males and 90 (30.4\%) females. All ticks were morphologically identified as belonging to the genus Hyalomma, with the most representative tick species being $H$. dromedarii (76.4\%), followed by Hyalomma impeltatum (23.3\%) and Hyalomma excavatum $(0.3 \%)$.

Data on sex and age of sampled camels along with the number and percentage positivity for TBPs are reported in Table 2. Out of 170 camels tested, 13 (7.6\%;
95\% CI: 4.3-12.8\%) were positive for at least one pathogen with $A$. platys being the highest prevalent pathogen (5.3\%; 95\% CI: 2.7-9.9\%), followed by A. phagocytophilum, Anaplasma sp., E. canis and $H$. canis ( $0.6 \%$ each; 95\% CI: $0.04-3.4 \%)$. None of the camels were found to be co-infected. All samples tested were negative for piroplasmids (Babesia spp. and Theileria spp.).

Representative sequences for each pathogen displayed $99.7-100 \%$ nucleotide identity with those available in the GenBank database. Two sequence types (ST) were identified for $A$. platys (ST1, $n=6,100 \%$ identity with KX818218; ST2, $n=3,99.7 \%$ identity with KX792011). One ST each for A. phagocytophilum (99.8\% identity with MN648675), and Anaplasma sp. (99.7\% identity with MN317255). One ST was identified for $H$. canis (100\% identity with MK673842) and for E. canis $(100 \%$ identity with KP182942), respectively.

Molecular identification of representative STs for $H$. canis, E. canis and Anaplasma spp. were supported by the distinct separation of species-specific clades, inferred from the phylogenetic analyses (Figs. 1, 2). In the ML tree, the representative ST of $H$. canis clustered within a well-supported clade including sequences of $H$. canis from wild canids and differing from other Hepatozoon spp. (Fig. 1). Rickettsiales herein detected (i.e. A. platys, A. phagocytophilum, Anaplasma sp., and E. canis) were included in two robust clades of the ML tree (Fig. 2). In particular, the ST of E. canis clustered in the clade including those of different hosts from different geographical regions (Fig. 2). Among Anaplasma spp., both STs of $A$. platys and of A. phagocytophilum were included in the corresponding species-specific paraphyletic clade (Fig. 2) whilst Anaplasma sp. clustered within the sister clade, which included sequences of A. marginale and A. ovis (Fig. 2).

Table 1 Primers and target genes of pathogens investigated

\begin{tabular}{|c|c|c|c|c|c|}
\hline Pathogens & Primers $\left(5^{\prime}-3^{\prime}\right)$ & Target gene & Product size (bp) & Cycling conditions & Reference \\
\hline \multirow[t]{2}{*}{ Babesia spp./Theileria spp. } & $\begin{array}{l}\text { RLBF: GAGGTAGTGACAAGAAAT } \\
\text { AACAATA }\end{array}$ & \multirow[t]{2}{*}{$18 \mathrm{~S}$ rRNA } & \multirow[t]{2}{*}{460} & \multirow[t]{2}{*}{$\begin{array}{l}95^{\circ} \mathrm{C}-600 \mathrm{~s}, 95^{\circ} \mathrm{C}-30 \mathrm{~s}, 52^{\circ} \mathrm{C}-30 \mathrm{~s} \\
(\times 40), 72^{\circ} \mathrm{C}-60 \mathrm{~s}, 72^{\circ} \mathrm{C}-420 \mathrm{~s}\end{array}$} & \multirow[t]{2}{*}[35]{} \\
\hline & RLBR:TCTTCGATCCCCTAACTTTC & & & & \\
\hline \multirow[t]{2}{*}{ Babesia spp. } & $\begin{array}{l}\text { PiroA: AATACCCAATCCTGACAC } \\
\text { AGGG }\end{array}$ & \multirow[t]{2}{*}{ 18S rRNA } & \multirow[t]{2}{*}{410} & \multirow[t]{2}{*}{$\begin{array}{c}95^{\circ} \mathrm{C}-600 \mathrm{~s}, 95^{\circ} \mathrm{C}-30 \mathrm{~s}, 62^{\circ} \mathrm{C}-30 \mathrm{~s} \\
(\times 35), 72^{\circ} \mathrm{C}-30 \mathrm{~s}, 72^{\circ} \mathrm{C}-420 \mathrm{~s}\end{array}$} & \multirow[t]{2}{*}[36]{} \\
\hline & $\begin{array}{l}\text { PiroB: TTAAATACGAATGCCCCC } \\
\text { AAC }\end{array}$ & & & & \\
\hline \multirow[t]{2}{*}{ Hepatozoon canis } & $\begin{array}{l}\text { HepF: ATACATGAGCAAAATCTC } \\
\text { AAC }\end{array}$ & \multirow[t]{2}{*}{ 18S rRNA } & \multirow[t]{2}{*}{625} & \multirow[t]{2}{*}{$\begin{array}{c}95^{\circ} \mathrm{C}-600 \mathrm{~s}, 95^{\circ} \mathrm{C}-30 \mathrm{~s}, 60^{\circ} \mathrm{C}-30 \mathrm{~s} \\
(\times 35), 72^{\circ} \mathrm{C}-60 \mathrm{~s}, 72^{\circ} \mathrm{C}-300 \mathrm{~s}\end{array}$} & \multirow[t]{2}{*}{ [37] } \\
\hline & HepR: CTTATTATTCCATGCTGCAG & & & & \\
\hline \multirow[t]{2}{*}{ Ehrlichia spp./Anaplasma spp. } & $\begin{array}{l}\text { EHR16SD: GGTACCYACAGAAGA } \\
\text { AGTCC }\end{array}$ & \multirow[t]{2}{*}{$16 \mathrm{~S}$ rRNA } & \multirow[t]{2}{*}{345} & \multirow[t]{2}{*}{$\begin{array}{l}95^{\circ} \mathrm{C}-120 \mathrm{~s}, 94^{\circ} \mathrm{C}-60 \mathrm{~s}, 54^{\circ} \mathrm{C}-30 \mathrm{~s} \\
(\times 40), 72{ }^{\circ} \mathrm{C}-30 \mathrm{~s}, 72{ }^{\circ} \mathrm{C}-300 \mathrm{~s}\end{array}$} & \multirow[t]{2}{*}{ [38] } \\
\hline & $\begin{array}{l}\text { EHR16SR:TAGCACTCATCGTTT } \\
\text { ACAGC }\end{array}$ & & & & \\
\hline
\end{tabular}


Representative sequences of pathogens detected in this study were deposited in the GenBank database under the accession numbers MN989008 (E. canis), MN989019 and MN989020 (A. platys), MN989201 (A. phagocytophilum), MN989202 (Anaplasma sp.) and MN989311 (H. canis).

\section{Discussion}

The high prevalence of tick infestation (68.2\%) and the circulation of TBPs (7.6\%) among camels in Saudi Arabia represents a risk to the health and welfare of these animals. Being blood-sucking arthropods, ticks can cause irritation and traumatic injuries to the skin of camels. The damaged skin will adversely affect the energy and water balance of camels in arid environment [44] and also attract flies leading possibly to myiasis infections [45]. The most prevalent tick species identified was $H$. dromedarii, which is considered as the main species parasitizing dromedary camels $[10,11]$. Hyalomma dromedarii is a thermophilic tick usually found in arid and hyper-arid regions [46] with the high prevalence reported from camels in Sudan, Iran, Egypt, Saudi Arabia and Tunisia, with an infection rate ranging between 49-89\% [10, 46-49] although it can also infest sheep, goats and horses [50]. This tick species is the principal vector of Theileria spp. of domestic and wild ungulates in Saudi Arabia [8]. The other two species herein identified in camels, $H$. impeltatum and $H$. excavatum, usually parasitize cattle and sheep $[8,51]$ and their finding in camels might be due to the husbandry practices in desert areas where all livestock share common inhabitancy, wandering in nature searching for water sources and grazing land.

The absence of Babesia spp. and Theileria spp. DNA in tested samples agrees with previous studies [13, 15] though these pathogens were diagnosed on some occasions by microscopic examination [23-25]. However, these results do not allow drawing any definitive conclusions about the occurrence of those pathogens in the sampled population, also considering the temporary nature of parasitemia in the blood of infected animals. To date, DNA of Theileria equi, T. annulata, T. mutans, T. ovis and B. caballi have been detected in blood of dromedaries [18, 52-55]. There is limited knowledge on piroplasms specific for camels and due to lack of experimental infections and molecular characterisation, the taxonomic status of some species such as Theileria camelensis [56], Theileria dromedarii [57], Theileria assiutis [58] and Babesia cameli [59] remain unresolved. The detection of $H$. canis in one camel represents, to our knowledge, the first report of this pathogen among camels, and this could be accounted for by the low host specificity and ubiquitous distribution of $H$. canis [60] and its vectors (i.e. Rhipicephalus sanguineus (sensu lato)). While $R$. sanguineus (s.l.) was not found on camels in this study, this tick is known to occur on dogs in Riyadh [61].

Among rickettsial organisms, A. platys was the most prevalent pathogen $(n=9,5.3 \%)$, though a much higher prevalence of Anaplasma spp. was detected in previous studies (i.e. 26\% from Saudi Arabia [21] and 61\% from Nigeria [55]). Anaplasma platys is a parasite with tropism for platelets having a wide host range, primarily being the causative agent of canine cyclic thrombocytopenia [62]. Even though definitive proof of the vector competence of $R$. sanguineus (s.l.) is currently lacking, this tick species is supposed to be the vector of $A$. platys [63]. Indeed, the presence of $A$. platys DNA amplified from $R$. sanguineus (s.l.) collected from Bactrian camels has been previously reported [64]. Although A. platys was initially considered to be a pathogen of dogs, recent reports support the occurrence of this pathogen in other livestock and humans suggesting a more broader host range for this pathogen [55]. Accordingly, E. canis mainly found in dogs, has been reported in domestic ruminants [65], with some strains diagnosed in dromedary camel of Saudi Arabia [21]. The occurrence of canine pathogens such as A.platys and E. canis in camels can be due to the co-inhabitance of these animals in desert area as well as to the strict affiliation of $R$. sanguineus (s.l.) to canids and

Table 2 Prevalence of infection among camels with tick-borne pathogens according to sex and age

\begin{tabular}{|c|c|c|c|c|c|c|}
\hline \multirow[t]{2}{*}{ Category } & Hepatozoon canis & Ehrlichia canis & Anaplasma platys & $\begin{array}{l}\text { Anaplasma } \\
\text { phagocytophilum }\end{array}$ & Anaplasma sp. & Total \\
\hline & Positive (\%) & Positive (\%) & Positive (\%) & Positive (\%) & Positive (\%) & Positive (\%) \\
\hline \multicolumn{7}{|l|}{ Sex } \\
\hline Male $(n=56)$ & - & $1(1.8)$ & $3(5.4)$ & - & - & $4(7.1)$ \\
\hline Female $(n=114)$ & $1(0.9)$ & - & $6(5.3)$ & $1(0.6)$ & $1(0.6)$ & $9(7.9)$ \\
\hline \multicolumn{7}{|l|}{ Age } \\
\hline$\leq 1$ year $(n=18)$ & - & - & $1(5.6)$ & $1(5.6)$ & $1(5.6)$ & $3(16.7)$ \\
\hline $1-5$ years $(n=106)$ & $1(0.9)$ & - & $3(2.8)$ & $1(0.9)$ & - & $5(4.7)$ \\
\hline $6-15$ years $(n=46)$ & - & $1(2.2)$ & $5(10.9)$ & - & - & $6(13)$ \\
\hline
\end{tabular}




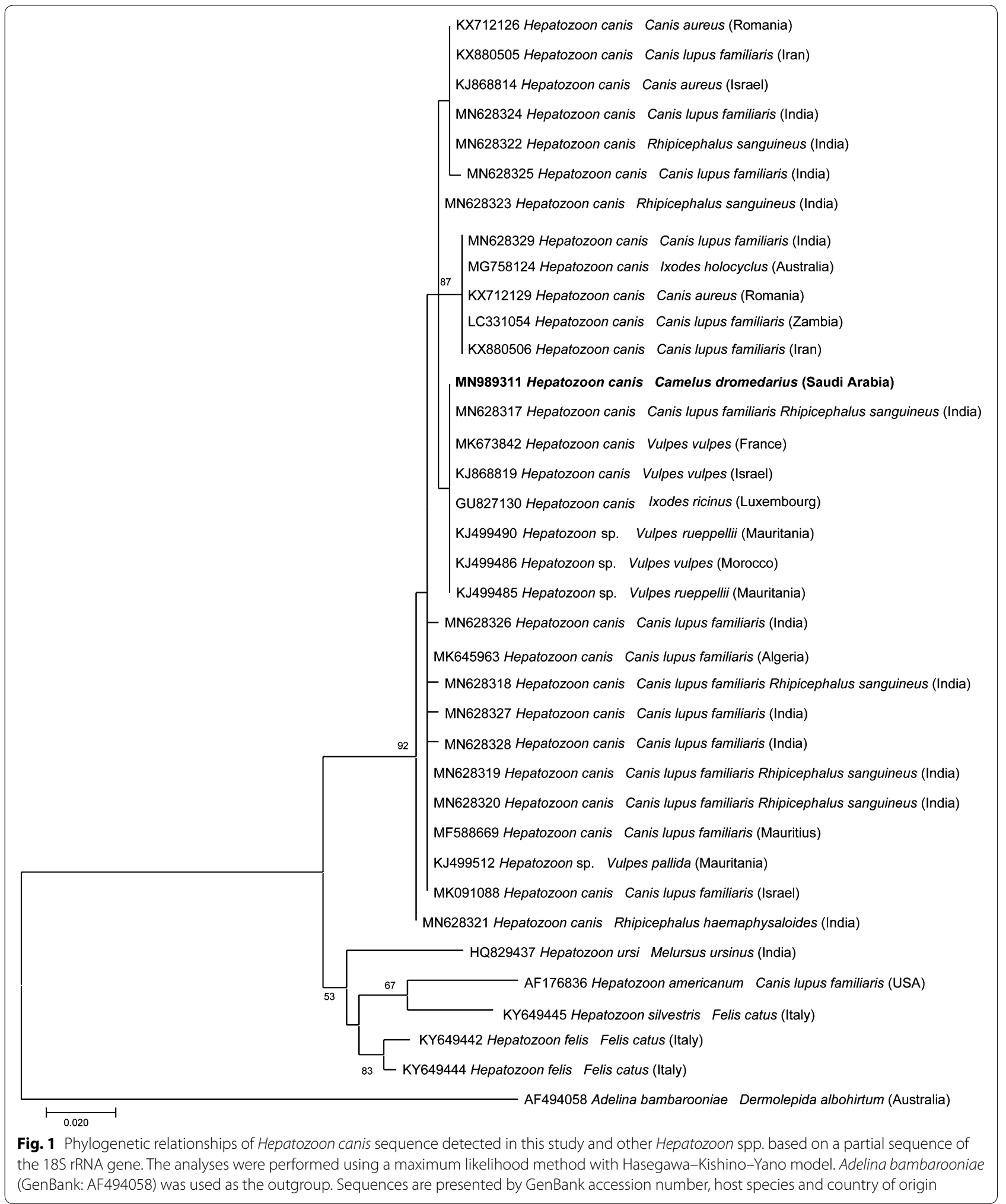

its ability in surviving a large array of environmental conditions [66]. Overall these ecological features give a hint about the possibility of transmission of these pathogens from dogs to camels.
For its zoonotic potential, the retrieval of $A$. phagocytophilum in camelids is relevant. This pathogen has been mostly diagnosed worldwide in wild roe deer and a wide variety of wildlife fauna [67-69]. In camels, 


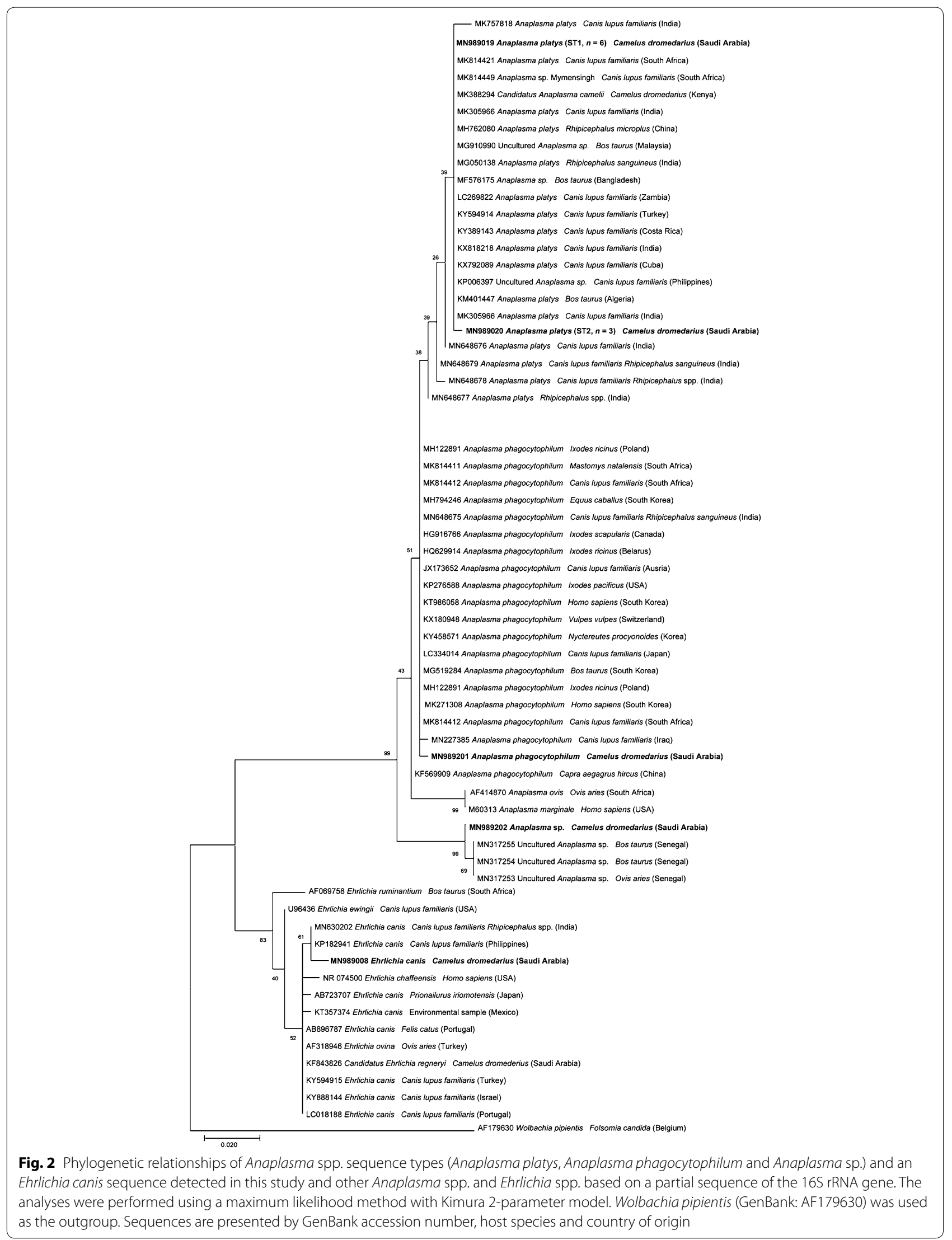


relatively high $A$. phagocytophilum positivity values have been reported in Tunisia (i.e. $29.2 \%$ based on serology) [70] and Iran (34.3\% based on PCR) [71]. While it has been demonstrated that several animal species may act as reservoirs of $A$. phagocytophilum [72, 73], the role of camelids remains to be ascertained. In the same way, the competence of Hyalomma spp. ticks as vectors for this pathogen needs confirmation.

Sequence analysis of the data revealed the circulation of two different STs of A. platys while pathogens like $H$. canis and E. canis had only one ST. High genetic variability has been already reported within Anaplasma spp. in different hosts from different geographical locations $[21,74]$. In the ML tree, two STs of A. platys from camels clustered within those of dogs irrespective of the geographical location, indicating its circulation amongst different animal species. This may occur due to a spillover of $A$. platys infection from canids to camelids [55]. Moreover, a ST of Anaplasma sp. found herein clustered with a group of Anaplasma spp. sequences from other ruminants from Senegal. This strengthens the possibility of genetic variation and high diversity of Anaplasma spp. The phylogenetic analysis showed that $H$. canis from camel clustered with those of wild carnivores (i.e. red foxes and of Ruppell's foxes) in a separate sister clade. Nonetheless, the finding of this parasite in a camel is probably a casual finding in an accidental host.

\section{Conclusions}

Our data indicate that $H$. dromedarii is the most prevalent tick infesting camels from Saudi Arabia and that these animals are exposed to many TBPs. The identification of pathogens such as A. platys, A. phagocytophilum, E. canis and $H$. canis not vectored by Hyalomma ticks suggests that further investigations should be carried out. It is advisable to undertake either molecular screening of the tick salivary glands or to perform transmission experiments using tick colonies, to obtain more reliable information on the vectoral role of these ticks. Since some of the detected pathogens are of zoonotic concern, adequate measures must be taken for the regular surveillance and control of zoonotic pathogens in camels.

\section{Abbreviations}

$\mathrm{Cl}$ : confidence interval; ML: maximum likelihood; ST: sequence type; s.l: sensu lato; TBP: tick-borne pathogen.

\section{Acknowledgments}

This project was financial supported by Shaqra University (Riyadh, Saudi Arabia) and the International Collaborative Program, King Saud University (Riyadh, Saudi Arabia) in collaboration with the Department of Veterinary Medicine, University of Bari (Bari, Italy).

\section{Authors' contributions}

ADA and DO conceived the study. MSA and ASA performed field works. VLN, RRSM and JAM-R performed laboratory works and analyzed data. ADA, $D O, V L N$ and RRSM wrote the first draft of the manuscript. RD, FDT and AS reviewed the manuscript. All authors read and approved the final manuscript.

\section{Funding}

FDT is the recipient of a research fellowship from Conselho Nacional de Desenvolvimento Científico e Tecnológico (CNPq; 313118/2018-3).

\section{Availability of data and materials}

All data generated or analyzed during this study are included in this published article.

\section{Ethics approval and consent to participate}

Ticks and blood samples involving this study were approved by the Ethical Research Committee, Shaqra University and complied with relevant guidelines for animal handling and welfare (Approval no. SH 05-2018).

\section{Consent for publication \\ Not applicable.}

\section{Competing interests}

All authors declare that they have no competing interests.

\section{Author details}

${ }^{1}$ Department of Biological Sciences, Faculty of Science and Humanities, Shaqra University, Ad-Dawadimi, Saudi Arabia. ${ }^{2}$ Dipartimento di Medicina Veterinaria, Università degli Studi di Bari, Bari, Italy. ${ }^{3}$ Department of Zoology, College of Science, King Saud University, Riyadh, Saudi Arabia. ${ }^{4}$ Life Science and Environment Sector, King Abdulaziz City for Science and Technology, Riyadh, Saudi Arabia. ${ }^{5}$ Istituto Zooprofilattico della Puglia e della Basilicata, Bari, Italy. ${ }^{6}$ Department of Pathobiology, Faculty of Veterinary Science, Bu-Ali Sina University, Hamedan, Iran. ${ }^{7}$ Department of Immunology, Oswaldo Cruz Foundation, Aggeu Magalhães Institute, Recife, Pernambuco, Brazil.

Received: 17 December 2019 Accepted: 17 February 2020 Published online: 28 February 2020

\section{References}

1. Guglielmone AA, Robbins RG, Apanaskevich DA, Petney TN, Estrada-Peña A, Horak IG. The hard ticks of the world. Dordrecht: Springer; 2015.

2. Dantas-Torres F, Chomel BB, Otranto D. Ticks and tick-borne diseases: a one health perspective. Trends Parasitol. 2012;28:437-46.

3. Jabbar A, Abbas T, Sandhu Z, Saddiqi HA, Qamar MF, Gasser RB. Tickborne diseases of bovines in Pakistan: major scope for future research and improved control. Parasit Vectors. 2015;8:283.

4. Faye B. Role, distribution and perspective of camel breeding in the third millennium economies. Emir J Food Agr. 2015;27:318-27.

5. FAOSTAT: Food and Agriculture Organization of the United Nations Statistics Division; 2019. http://www.fao.org/faostat. Accessed 16 Dec 2019.

6. Faye B. The camel today: assets and potentials. Anthropozoologica. 2014;49:167-77.

7. Megersa B. An epidemiological study of major camel diseases in the Borana lowland, southern Ethiopia. Oslo: Drylands Coordination Group; 2010.

8. Hoogstraal H, Wassef H, Büttiker W. Ticks (Acarina) of Saudi Arabia Fam. Argasidae, Ixodidae. In: Büttiker W, Krupp F, Nader I, Schneider W, editors. Fauna of Saudi Arabia. Basel: Karger Libri; 1981. p. 25-110.

9. Banaja AA, Ghandour AM. A review of parasites of camels (Camelus dromedarius) in Saudi Arabia. J King Abdulaziz Univ Sci. 1994;6:75-86.

10. Elghali A, Hassan SM. Ticks (Acari: Ixodidae) infesting camels (Camelus dromedarius) in northern Sudan. Onderstepoort J Vet Res. 2009;76:177-85.

11. Fard SRN, Fathi S, AsI EN, Nazhad HA, Kazeroni SS. Hard ticks on onehumped camel (Camelus dromedarius) and their seasonal population dynamics in Southeast,Iran. Trop Anim Health Prod. 2012;44:197-200.

12. El Kady GA. Protozoal parasites in tick species infesting camels in Sinai Peninsula. J Egypt Soc Parasitol. 1998;28:765-76. 
13. Al-Deeb MA, Muzaffar SB, Abu-Zeid YA, Enan MR, Karim S. First record of a spotted fever group Rickettsia sp. and Theileria annulata in Hyalomma dromedarii (Acari: Ixodidae) ticks in the United Arab Emirates. Florida Entomol. 2015;98:135-9.

14. Barghash S, Hafez A. Molecular detection of pathogens in ticks infesting camels in Matrouh Governorate, Egypt. J Bacteriol Parasitol. 2016;7:2.

15. Alanazi AD, Abdullah S, Helps C, Wall R, Puschendorf R, ALHarbi SA, et al. Tick-borne pathogens in ticks and blood samples collected from camels in Riyadh Province. Saudi Arabia. Int J Zool Res. 2018;14:30-6.

16. Dugat T, Lagrée AC, Maillard R, Boulouis HJ, Haddad N. Opening the black box of Anaplasma phagocytophilum diversity: current situation and future perspectives. Front Cell Infect Microbiol. 2015;5:61.

17. Beugnet $F$, Marié JL. Emerging arthropod-borne diseases of companion animals in Europe. Vet Parasitol. 2009;163:298-305.

18. Sazmand A, Harl J, Eigner B, Hodžić A, Beck R, Hekmatimoghaddam S, et al. Vector-borne bacteria in blood of camels in Iran: new data and literature review. Comp Immunol Microbiol Infect Dis. 2019;65:48-53.

19. Tate CM, Howerth EW, Mead DG, Dugan VG, Luttrell MP, Sahora Al, et al. Anaplasma odocoilei sp nov (family: Anaplasmataceae) from white-tailed deer (Odocoileus virginianus). Ticks Tick Borne Dis. 2013;4:110-9.

20. Li H, Zheng YC, Ma L, Jia N, Jiang BG, Jiang RR, et al. Human infection with a novel tick-borne Anaplasma species in China: a surveillance study. Lancet Infect Dis. 2015;15:663-70.

21. Bastos ADS, Mohammed OB, Bennett NC, Petevinos C, Alagaili AN. Molecular detection of novel Anaplasmataceae closely related to Anaplasma platys and Ehrlichia canis in the dromedary camel (Camelus dromedarius). Vet Microbiol. 2015;179:310-4.

22. Mugunieri LG, Mtimet N, Enock K, Costagli R, Gulaid I. Saudi Arabia end-market requirements and the implications for Somaliland livestock exports. Nairobi: ILRI Research Report; 2016.

23. Ismael AB, Swelum AA, Khalaf AF, Abouheif MA. Clinical, haematological and biochemical alterations associated with an outbreak of theileriosis in dromedaries (Camelus dromedarius) in Saudi Arabia. Pak Vet J. 2014;34:209-13.

24. Swelum $A A$, Ismael $A B$, Khalaf $A F, A b o u h e i f M A$. Clinical and laboratory findings associated with naturally occurring babesiosis in dromedary camels. Bull Vet Inst Pulawy. 2014;58:229-33.

25. Ismael AB, Swelum AA, Khalaf AF, Alowaimer AN. First evidence of natural anaplasmosis in Camelus dromedarius in Saudi Arabia. J Camel Pract Res. 2016;23:95-100.

26. Mohammed AA, Sharma A, Saied MAM, Osman OH, Al-Balowi MH, Salih DA, et al. Lack of evidence for infection of camels with tick-borne diseases in Riyadh Region, Saudi Arabia. Sudan J Vet Res. 2017;32:39-40.

27. Apanaskevich D, Horak I. The genus Hyalomma Koch, 1844. II. Taxonomic status of H. (Euhyalomma) anatolicum Koch, 1844 and H. (E.) excavatum Koch, 1844 (Acari: Ixodidae) with redescriptions of all stages. Acarina. 1844;2005(13):181-97.

28. Apanaskevich DA, Horak IG. The genus Hyalomma Koch, 1844. III. Redescription of the adults and larva of H. (Euhyalomma) impressum Koch, 1844 (Acari: Ixodidae) with a first description of its nymph and notes on its biology. Folia Parasitol. 1844;2007(54):51-8.

29. Apanaskevich DA, Horak IG. The genus Hyalomma Koch, 1844: V. Reevaluation of the taxonomic rank of taxa comprising the H. (Euhyalomma) marginatum Koch complex of species (Acari: Ixodidae) with redescription of all parasitic stages and notes on biology. Int J Acarol. 2008;34:13-42.

30. Apanaskevich DA, Santos-Silva MM, Horak IG. The genus Hyalomma Koch, 1844. IV. Redescription of all parasitic stages of H. (Euhyalomma) lusitanicum Koch, 1844 and the adults of H. (E.) franchinii Tonelli Rondelli, 1932 (Acari: Ixodidae) with a first description of its immature stages. Folia Parasitol. 2008;55:61-74.

31. Apanaskevich DA, Horak IG. The genus Hyalomma Koch, 1844. IX. Redescription of all parasitic stages of H. (Euhyalomma) impeltatum Schulze \& Schlottke, 1930 and H. (E.) somalicum Tonelli Rondelli, 1935 (Acari: Ixodidae). Syst Parasitol. 1935;2009(73):199-218.

32. Apanaskevich DA, Filippova NA, Horak IG. The genus Hyalomma Koch, 1844. X. Redescription of all parasitic stages of H. (Euhyalomma) scupense Schulze, 1919 ( $=$ H. detritum Schulze) (Acari: Ixodidae) and notes on its biology. Folia Parasitol. 2010;57:69-78.

33. Apanaskevich DA, Horak IG. The genus Hyalomma. XI. Redescription of all parasitic stages of H. (Euhyalomma) asiaticum (Acari: Ixodidae) and notes on its biology. Exp Appl Acarol. 2010;52:207-20.
34. Estrada-Peña A, Pfäffle MP, Petney TN. Genus Hyalomma Koch, 1844. In: Estrada-Peña A, Mihalca AD, Petney TN, editors. Ticks of Europe and North Africa: a guide to species identification. Cham: Springer Nature International; 2017. p. 343-404.

35. Gubbels JM, de Vos AP, van der Weide M, Viseras J, Schouls LM, de Vries E, et al. Simultaneous detection of bovine Theileria and Babesia species by reverse line blot hybridization. J Clin Microbiol. 1999;37:1782-9.

36. Olmeda AS, Armstrong PM, Rosenthal BM, Valladares B, del Castillo A, de Armas F, et al. A subtropical case of human babesiosis. Acta Trop. 1997;67:229-34.

37. Inokuma H, Okuda M, Ohno K, Shimoda K, Onishi T. Analysis of the $18 \mathrm{~S}$ rRNA gene sequence of a Hepatozoon detected in two Japanese dogs. Vet Parasitol. 2002;106:265-71.

38. Martin AR, Brown GK, Dunstan RH, Roberts TK. Anaplasma platys: an improved PCR for its detection in dogs. Exp Parasitol. 2005;109:176-80.

39. Kimura M. A simple method for estimating evolutionary rate of base substitutions through comparative studies of nucleotide sequences. J Mol Evol. 1980;16:111-20.

40. Hasegawa M, Kishino H, Yano T. Dating of the human-ape split by a molecular clock of mitochondrial DNA. J Mol Evol. 1985;22:160-74.

41. Kumar S. Molecular evolution and phylogenetics. New York: Oxford University; 2000.

42. Kumar S, Stecher G, Li M, Knyaz C, Tamura K. MEGA X: molecular evolutionary genetics analysis across computing platforms. Mol Biol Evol. 2018;35:1547-9.

43. Rózsa L, Reiczigel J, Majoros G. Quantifying parasites in samples of hosts. J Parasitol. 2000;86:228-32.

44. Schmidt-Nielsen K. Desert animals: physiological problems of heat and water. New York: Oxford University Press; 1964.

45. Higgins AJ. Common ectoparasites of the camel and their control. Br Vet J. 1985;141:197-216.

46. Moshaverinia A, Moghaddas E. Prevalence of tick infestation in dromedary camels (Camelus dromedarius) brought for slaughter in Mashhad abattoir, Iran. J Parasit Dis. 2015;39:452-5.

47. Ghoneim NH, Abdel-Moein KA, Zaher HM. Molecular detection of Francisella spp. among ticks attached to camels in Egypt. Vector Borne Zoonotic Dis. 2017;17:384-7.

48. Alanazi AD, Al-Mohammed HI, Alyousif MS, Said AE, Salim B, Abdel-Shafy $\mathrm{S}$, et al. Species diversity and seasonal distribution of hard ticks (Acari: IxOdidae) infesting mammalian hosts in various districts of Riyadh Province, Saudi Arabia. J Med Entomol. 2019;56:1027-32.

49. Selmi R, Said MB, Dhibi M, Yahia HB, Messadi L. Improving specific detection and updating phylogenetic data related to Anaplasma platys-like strains infecting camels (Camelus dromedarius) and their ticks. Ticks Tick Borne Dis. 2019;10:101260.

50. Hoogstraal H, Aeschlimann A. Tick-host specificity. Bull Soc Entomol Suiss. 1982;55:5-32.

51. El-Azazy OME, El-Metenawy TM, Wassef HY. Hyalomma impeltatum (Acari: Ixodidae) as a potential vector of malignant theileriosis in sheep in Saudi Arabia. Vet Parasitol. 2001;99:305-9.

52. Qablan MA, Sloboda M, Jirků M, Oborník M, Dwairi S, Amr ZS, et al. Quest for the piroplasms in camels: identification of Theileria equi and Babesia caballi in Jordanian dromedaries by PCR. Vet Parasitol. 2012;186:456-60.

53. Tomassone L, Grego E, Callà G, Rodighiero P, Pressi G, Gebre S, et al. Ticks and tick-borne pathogens in livestock from nomadic herds in the Somali Region, Ethiopia. Exp Appl Acarol. 2012;56:391-401.

54. Bahrami S, Tabandeh MR, Nikbin A, Alborzi AR, Ghadrdan AR. Prevalence and phylogenetic analysis of Theileria equi in Iranian dromedaries. Arch Razi Inst. 2016;71:169-75.

55. Lorusso V, Wijnveld M, Latrofa MS, Fajinmi A, Majekodunmi AO, Dogo $A G$, et al. Canine and ovine tick-borne pathogens in camels, Nigeria. Vet Parasitol. 2016;228:90-2.

56. Yakimoff W, Schokhor NI, Kosel-Kine PM. In Maladies animales du Turkestan russe à parasites endoglobulaires. Bull Soc Pathol Exot. 1917;10:303-9.

57. Mishra AK, Sharma NN, Raghavendra Rao J. Theileria dromedarii n. sp. from Indian camels (Camelus dromedarius). Riv Parassitol. 1987;4:99-102.

58. Abd-Elmaleck BS, Abed GH, Mandour AM. Theileria assiutis n. sp. infecting Camelus dromedarius at Assiut locality. Upper Egypt. EC Microbiol. 2015;2:307-16. 
59. Abd-Elmaleck BS, Abed GH, Mandour AM. Light and electron microscopically study of Babesia cameli $\mathrm{n}$. sp. infecting camels (Camelus dromedarius). Int J Bact Virol. 2016;1:002

60. Smith TG. The genus Hepatozoon (Apicomplexa: Adeleina). J Parasitol. 1996:82:565-85.

61. Chandra S, Smith K, Alanazi AD, Alyousif MS, Emery D, Šlapeta J. Rhipicephalus sanguineus sensu lato from dogs and dromedary camels in Riyadh, Saudi Arabia: low prevalence of vector-borne pathogens in dogs detected using multiplexed tandem PCR panel. Folia Parasitol. 2019;66:007.

62. Gaff HD, Kocan KM, Sonenshine DE. Tick-borne rickettsioses II (Anaplasmataceae). In: Sonenshine DE, Roe RM, editors. Biology of ticks. New York: Oxford University; 2014. p. 251-77.

63. Latrofa MS, Dantas-Torres F, Giannelli A, Otranto D. Molecular detection of tick-borne pathogens in Rhipicephalus sanguineus group ticks. Ticks Tick Borne Dis. 2014;5:943-6.

64. Li Y, Yang J, Chen Z, Qin G, Li Y, Li Q, et al. Anaplasma infection of Bactrian camels (Camelus bactrianus) and ticks in Xinjiang, China. Parasit Vectors. 2015:8:313.

65. Zhang J, Kelly P, Guo W, Xu C, Wei L, Jongejan F, et al. Development of a generic Ehrlichia FRET-qPCR and investigation of ehrlichioses in domestic ruminants on five Caribbean islands. Parasit Vectors. 2015;8:506.

66. Dantas-Torres F, Latrofa MS, Annoscia G, Giannelli A, Parisi A, Otranto D. Morphological and genetic diversity of Rhipicephalus sanguineus sensu lato from the New and Old Worlds. Parasit Vectors. 2013;6:213.

67. Tinkler SH, Firshman AM, Sharkey LC. Premature parturition, edema, and ascites in an alpaca infected with Anaplasma phagocytophilum. Can Vet J. 2012;53:1199-202.
68. Overzier E, Pfister K, Herb I, Mahling M, Böck G Jr, Silaghi C. Detection of tickborne pathogens in roe deer (Capreolus capreolus), questing ticks (Ixodes ricinus) and ticks infesting roe deer in southern Germany. Ticks Tick Borne Dis. 2013;4:320-8.

69. Atif FA. Anaplasma marginale and Anaplasma phagocytophilum: rickettsiales pathogens of veterinary and public health significance. Parasitol Res. 2015;114:3941-57.

70. Ben Said M, Belkahia H, Sayahi L, Aloui M, Jemli MH, Mohamed B, et al. First serological study of the prevalence of Anaplasma phagocytophilum in dromedary (Camelus dromedarius) in Tunisia. Bull Soc Pathol Exot. 2013:107:1-6.

71. Bahrami S, Hamidinejat H, Tafreshi ARG. First molecular detection of Anaplasma phagocytophilum in dromedaries (Camelus dromedarius). J Zoo Wildl Med. 2018:49:844-8.

72. Keesing F, Hersh MH, Tibbetts M, McHenry DJ, Duerr S, Brunner J, et al. Reservoir competence of vertebrate hosts for Anaplasma phagocytophilum. Emerg Infect Dis. 2012;18:2013-6.

73. Majazki J, Wüppenhorst N, Hartelt K, Birtles R, von Loewenich FD. Anaplasma phagocytophilum strains from voles and shrews exhibit specific ankA gene sequences. BMC Vet Res. 2013;9:235.

74. De Arcangeli S, Balboni A, Dondi F. Genetic diversity and molecular epidemiology of Anaplasma. Infect Genet Evol. 2017;49:195-211.

\section{Publisher's Note}

Springer Nature remains neutral with regard to jurisdictional claims in published maps and institutional affiliations.
Ready to submit your research? Choose BMC and benefit from:

- fast, convenient online submission

- thorough peer review by experienced researchers in your field

- rapid publication on acceptance

- support for research data, including large and complex data types

- gold Open Access which fosters wider collaboration and increased citations

- maximum visibility for your research: over 100M website views per year

At BMC, research is always in progress.

Learn more biomedcentral.com/submissions 